\title{
LOCAL WISHES MAP AS A TOOL FOR PROMOTING DIALOGUE AND DEVELOPING HEALTHY CITIES
}

\section{MAPA DOS DESEJOS LOCAIS COMO UMA FERRAMENTA PARA PROMOÇÃO DO DIÁLOGO E DO DESENVOLVIMENTO DE CIDADES SAUDÁVEIS}

\author{
Ana Maria Girotti Sperandio ${ }^{1}$ \\ University of Campinas, Campinas, SP, Brazil, amgspera@gmail.com \\ Murilo Urssi Malek-Zadeh ${ }^{2}$ \\ University of Campinas, Campinas, SP, Brazil, murilourssi@gmail.com \\ João Luiz de Souza Arêas ${ }^{3}$ \\ City Hall of Sorocaba, Sorocaba, SP, Brazil, arq.areas@gmail.com \\ Lauro Luiz Francisco Filho ${ }^{4}$ \\ University of Campinas, Campinas, SP, Brazil, Ilfilho@fec.unicamp.br
}

\begin{abstract}
The healthy cities development requires intersectoral governance. However, at cities at low resource condition, there are many barriers to achieve this goal. Therefore, it was developed a low-cost investigative procedure with the potential to systematize sectoral wishes. This procedure covers two steps. These steps can be applied in different groups and after compare results. The first one is a conversation guided by a list of question-related to how individuals understand: (i) what is a "healthy city"; (ii) what is the relation between urban planning and health promotion; (iii) how intersectoral dialogue can be achieved; (iv) local potentialities and issues, and how collective solutions can be reached. At this phase, the information is gathered to understand how individuals consider a healthy city or health promotion, the relation between urban planning and urban health, how the dialogue between sectors can be achieved, and local issues and how collective solutions can be succeeded. At the second step, individuals represent their wishes through notations or setting icons on the map of the city. This procedure was conducted at Holambra, in 2017. This city's prefecture asked for assistance in order to Holambra join the Potential Healthy Municipalities Network. The investigated sectors were the government and the urban population. A map of common wishes was created, as well as the maps of sectoral wishes. These maps can be used as a tool for promoting dialoguing and monitoring the process of politics implementation.
\end{abstract}

Keywords: Urban Planning Heathy. Local Wishes Map. Governance. Social participation. Intersectoriality

\begin{abstract}
Resumo
O desenvolvimento de cidades saudáveis necessita da governança intersetorial. Entretanto, em cidades com poucos recursos, existem diversos obstáculos para alcançar esse objetivo. Portanto, foi desenvolvido um procedimento investigativo de baixo custo, com potencial de sistematizar os desejos setoriais. Esse procedimento engloba duas etapas. Essas etapas podem ser aplicadas em diferentes grupos e depois os resultados serem comparados. O primeiro passo é uma conversa guiada por uma lista de perguntas referentes à forma como os indivíduos entendem: (i) o que é "cidade saudável"; (ii) qual a relação entre planejamento urbano e promoção da saúde; (iii) como o diálogo entre setores pode ser alcançado; (iv) potencialidades e dificuldades locais e como podem alcançar soluções coletivas. Na segunda etapa, os indivíduos representam seus desejos através de anotações ou por ícones no mapa da cidade. Esse procedimento foi conduzido em Holambra, em 2017. A prefeitura dessa cidade requisitou assistência para participar da Rede de Municípios Potencialmente Saudáveis. Os setores observados foram "gestores" e "comunidade". Um mapa de desejos comuns foi criado, bem como mapas de desejos setoriais. Esses mapas podem ser utilizados como ferramentas para promover o diálogo $e$ monitorar o processo de implementação das políticas públicas.
\end{abstract}

Palavras-chave: Planejamento Urbano Saudável. Mapa dos Desejos Local. Governança; Participação Social. Intersetorialidade.

How to cite this article:

SPERANDIO, Ana Maria Girotti et al. Local wishes map as a tool for promoting dialogue and developing healthy cities. PARC Research in Architecture and Building Construction, Campinas, SP, v. 10, p. e019002, jan. 2019. ISSN 1980-6809. Available at: <https://periodicos.sbu.unicamp.br/ojs/index.php/parc/article/view/8652312>. Date accessed: 29 dec. 2018. doi:https://doi.org/10.20396/parc.v10i0.8652312. 


\section{Introduction}

The healthy city concept is defined by Brandão (2010) as a city in which there is a relation between population and government that favors the citizen's well-being, instead of a city where human development index is high. This concept was developed based on discussion, innovation and openness, and after the creation of this idea, there was a selfevaluation moment, inspiring leaderships forms that goes beyond sectoral and professional barriers (TSOUROS, 2017). Along with healthy city idea, the concept of health promotion was developed.

The health promotion covers the practices related to promotion of happiness, healthy lifestyle, equity, positive cultural and physical environmental and, also, healthcare (PEDERSON; ROOTMAN, 2017). Therefore, the health concept transcends the medical sectors, making the interdisciplinarity and intersectorality necessary. The healthy cities studies consider this need and incorporate subjects as urban planning, political sciences and law sciences to the health promotion discussion. The evolution of health promotion concept occurred through many reports, for instance: Ottawa Charter for Health Promotion, Lalonde Report, A Global Charter for Public's Health and The 2030 Agenda for Sustainable Development. This last report is important because it provides global goals for mankind, and healthy cities development can be used for the achievement of some of these goals.

In Latin America, the healthy cities development faces some difficulties as the lack of economic resources, which causes the lack of basic services, as water, sanitation, roads, healthy living conditions, among others. Also, some Latin American cities exclude part of their citizens from the decision-making processes, while elites and interest groups dominate the governance process (RICE et al., 2017).

Therefore, the Laboratory of Urban Investigations (LABINUR) of FEC at University of Campinas has developed the tool LOCAL WISHES MAP (LWM) to favor the social participation through asking the population about their wishes related to the city.

The authors consider the principles and values to a healthy city based on Brazilian National Health Promotion Policy, 2014, (Política Nacional de Promoção da Saúde), therefore equity, social participation, empowerment and intersectorality are the principles to promote some values, as the recognition of individual subjectivity; solidarity, respect to diversity, co-responsibility, justice and social inclusion (BRASIL, 2014).

This study will present important concepts to understand about healthy cities and the strategies used in their development, as well as the forms in which these concepts articulate between themselves and thoughts from other scientific areas. This articulation is important to make clear that the interdisciplinary knowledge is not (and cannot be) neglected, despite which field they are from. Then, the LWM is presented as investigative procedure that can be both a way of dialoguing between the government and civil society, and a tool for politics monitoring. Also, the orientation for designing this procedure and for the systematization of results will be described. Finally, it will be discussed how it relates itself with the presented concepts and how it can be significant to the construction process of the healthy city.

\section{Healthy Cities}

The fundamental elements considered to achieve governance for healthy cities are: social participation, sense of belonging, identification of stakeholders, autonomy, coalitions, intersectoral governance and equity. Furthermore, those concepts have a 
synergy capable to strengthen each other, so the achievement of some of them without the others is a harder challenge than achieving all the six elements simultaneously. The elements are explained below, how they relate to each other, as how they can be useful to make the collective wishes became the healthy city development.

The governance concept does not refer only to the way which governors make their decisions, but the whole exercise of power forms that are related to public issues, taken by public power, by media, by organized civil society and others (UN HABITAT, 2002). Health governance can be distinguished from governance for health: the first one refers to the management and strengthening of health systems; whereas the joint action of many society sectors to achieve a common goal to public health is called governance for health (KICKBUSCH; GLEICHER, 2012). This study uses the second meaning of governance as a goal. The governance, on one hand, can be positive and democratic and on the other hand it can be inefficient and bring harmful effects to urban health (BURRIS et al., 2007). Therefore, it is important that dialogue pathways exist and that they allow citizens to both find their wishes convergence and help with the beginning of coalition formation whose objectives are related to health promotion. On this study, a specific kind of governance is understood as both criteria and condition in order to develop a healthy city, which has relation to the population's perception of the city, engagement, as well as enlarging their autonomy in order to achieve collective governance.

\section{Tool requirements}

The tools for the healthy cities' development need to incorporate some qualities to be useful. The first one is the social participation in the decision making, as it is possible to observe its importance at many experiences around the globe (SIMOS; DE LEEUW, 2017). This participation makes the healthy city development became resilient, because it is easier to a new government impose your individual agenda if there is not popular pressure to maintenance of the healthy city project (WERNA et al., 2014). Besides that, the social participation is important to healthy cities development, because this practice favors others elements, above mentioned, as the sense of belonging and the identification of stakeholder.

The sense of belonging is related to the feeling of being "at home" and being "safe", and those feelings can appear as a consequence of many elements: language, gender, class, nation, race, age, and how the individual participates within the society, in terms of rights and duties (YUVAL-DAVIS, 2006). Therefore, we understand that the sense of belonging can be positively transformed in the "sense of belonging to a participative society which aims to the health promotion", through the exercise of the social participation in the governance for health. It can help the promotion of collective health, as it can benefit the individuals, for example, by enhancing its meaning in life (LAMBERT et al., 2013).

Social participation also can be useful to the identification of stakeholders. There is a polysemy about the definition of the concept of stakeholder. It can be understood as an influential individual, a collaborator, a recipient or a claimant it depends on the way the influence is exercised (actively or passively), the sense of obligation that an individual has (e.g. moral or contractual), and even on the contact frequency between leadership and its goal (MILES, 2017). For the healthy cities' development, the many forms of stakeholders can be useful, for example: an engaged citizen, a politician concerned with health issues, an NGO activist, a syndical leader or a business representative. These stakeholders can be identified once there is social participation and some individuals show themselves as more engaged than others. 
The sense of belonging and the stakeholder's action can influence new political forms which can help new achievements for health. These innovative politics created by social participation are the basis of autonomy. The meaning of autonomy in this study is defined as the art of organizing hope, or the willingness to create what has not yet been developed (DINERSTEIN, 2015). So, the autonomy with participation requires empowerment. The citizen's empowerment is created by dialogue and reflection of the population which intends to both participate in the politics and create new and more democratic forms of governance (DOORIS; HERITAGE, 2013). However, it would not be aligned with the democratic values exposed above if the political practices are authoritarian. Thus, the tools of healthy cities cannot impose a certain rationality form or try to make a biased social participation.

The pedagogical theory of Freire (1968) is aligned with these autonomy values. Accordingly, to this theory, knowledge is not a steady entity which can be seized, but an action-reflexional process in order to promote equity and autonomy. So, the education has to be an instrument of social changes. Therefore, knowledge cannot come from an external source to the participants, but has to be created through those individuals that educate themselves by dialogue, observation and reflexional processes. We believe that through social participation, sense of belonging, autonomy and stakeholder's action, the creation of politics in order to benefit the healthy cities gets closer to becoming true.

Nevertheless, if a social change happens by a democratic action, it is necessary that the many sectors of the society dialogue between themselves. The stakeholders are important for simplifying the work of sectors dialoguing, because this leadership can be considered as a representative of one group. However, as long as the governance has the democratically health promotion goal, the conflicts and the misaligned wishes must be observed. It implies that a double consideration is required: the power goes through many pathways, as it is exercised in distinct senses of the same orientation.

To understand the complexity of power, we use the micro-physics of power theory from Foucault (1979), once it discusses the concatenation of the forces which can be both repressive and creative as they come from many sources and go through many pathways and instrument. Therefore, a dialogue already is a tense situation, it is an event in which the forces of those who dialogue can start conflicting and one may end up overcoming the other (with more or less resistance) as it could also happen the confluence of interests which gives birth to a coalition.

Based on the assumption that the power can be a creative source, the coalition also can be a creation enhancer. The coalition is formed by the union of people who have similar values towards a common objective, from a political party or not. Through this union, there is an addition of political power which allows more strength to achieve the group's goals. The coalition formation that aims to health promotion is benefited when it is created with attention to the different forms of knowledge that individuals have, to the inclusion and exclusion processes and to the sector's common values that are related to a healthy city (CLAVIER; O'NEILL, 2017). Also, if the members of the coalition share the same broad view of healthiness, they can easily agree with the strategies to health promotion (ARONSON; NORTON; KEGLER, 2007). Therefore, the dialogue and the agreement between the different sectors and disciplines are important to coalition formation.

From this, it emerges the importance of interdisciplinarity and the looking for stakeholders which can play the vector's role through disciplines and sectors (CLAVIER; O'NEILL, 2017). Two important sectors for developing politics that support healthy cities 
are citizens and the government (DE ANDRADE et al., 2015). Thus, a coalition's first step can be the performing data collection about both sectors' wishes.

The stakeholder's role at coalition formation lays down on encouraging the individuals to speak, and also on transporting this information to other sectors. These two roles are fundamental because the forms of knowledge diversification between sectors and professions exist. Such individuals, with similar values but distinct vocabulary, can disagree without need. For example, "politics" can mean "the standard methods" to a bureaucrat, while it can also can mean "what is wanted" to a politician (DE LEEUW, 2017). Therefore, a stakeholder who has interdisciplinary knowledge can serve as a translator and dialogue mediator, encouraging the coalition formation in favor of health promotion and healthy city. When there is coalition formation and relations between sectors for governance for health, the intersectoral governance is achieved.

The intersectoral governance means the continuous accommodation process of many interests from the society groups through a joint action to the common well-being, so the individual, institutional, public and private participations have to overcome conflicts and divergences for a positive goal (SORENSEN, 1995). The intersectoral action needs the engagement of the relevant sectors in a field in order to implement a project while individuals from these sectors keep making an effective and collaborative work, with the stakeholders helping the dialogue between the sectors (DE LEEUW, 2017).

This dialogue is an action which benefits the public sphere to become more democratic. The notion of "public" is different from the "mass". The first is a group of individuals which maintain a dialogue between themselves, and they can answer back without external authority coercion. The second notion refers to a group which do not answer back, but receive information more than bring individual opinions to debate (HABERMAS, 1989). Thus, according to Habermas's proposal, the politics must be created from the public debate, instead of from the mass population. Then, this public opinion or, in this case, "public wishes", can be used to guide the intersectoral governance, which becomes legitimated by social participation.

The creation of management forms that can accommodate the wishes of each group becomes necessary as long as each sector has their specificities and can indicate different issues and solutions that are important for them. So, at the beginning there is the question "which elements will be considered to understand the local objectives for a healthy city development?" At this point, the willingness to consider many elements from several sectors is beneficial, because only through a broad demand consideration it is possible to achieve equity (SPERANDIO; FRANCISCO FILHO; MATTOS, 2016). As long as more elements are considered at the planning work, more possibilities to relate sectoral demands rises, which enable more formation of coalitions.

Thus, the role of individual who belongs to a city sector is to create demands and reinforce it. This participation helps people to develop their sense of belonging, and creates opportunities to stakeholders to appear. The stakeholders translate the demands to other sectors and helps with the information transporting and coalition formation. The researchers assist at demands gathering in collaboration with the stakeholder's action. They also create their own stakeholders which will have an effect on decision making. Therefore, the researcher can be a stakeholder who offers a systematized version of both wishes and power networks that permeate the city. The understanding of these scenarios helps the intersectoral governance for health, while enhancing equity.

The equity at urban health is a value pointed by World Health Organization's report, which state that the urban health's progress is related to the promotion of health equity 
(WORLD HEALTH ORGANIZATION, 2016). So, instruments that allow this achievement must be developed. The equity is here defined not as a social equalization in the sense of making equal individuals, but in the sense that individuals are different and so are their needs, which must be solved. The equity can be reinforced through social participation at local management. Not through vote, but through reflexive work of dialogue, through making demands to rise and through the attempt of realizing what can be better in the regular life.

The elements discussed above help the achievement of health promotion, from collective wishes (social participation), to healthy city development. The social participation offers both possibilities to citizens develop their sense of belonging related to the healthy city, and promotes stakeholder's identification. These two elements promote the autonomy and the creation of empowerment. The innovative potential of autonomy, the political power from empowerment and the stakeholder's action make it easier for the coalition formation. The creative power of coalition is useful for intersectoral governance for health, which can finally achieve more equity. And all this process can be made based in a democratic public sphere (dialogue). In sum, the democratic exercising reinforces the democracy itself which is a healthy city value. Through Sperandio et al. (2017) study, an example of this interface between urban planning and healthy city was developed, based on health promotion principles and values. The theoretical sequence of a healthy city's development is illustrated in Figure 1.

Figure 1. Theoretical sequence of a healthy city's development

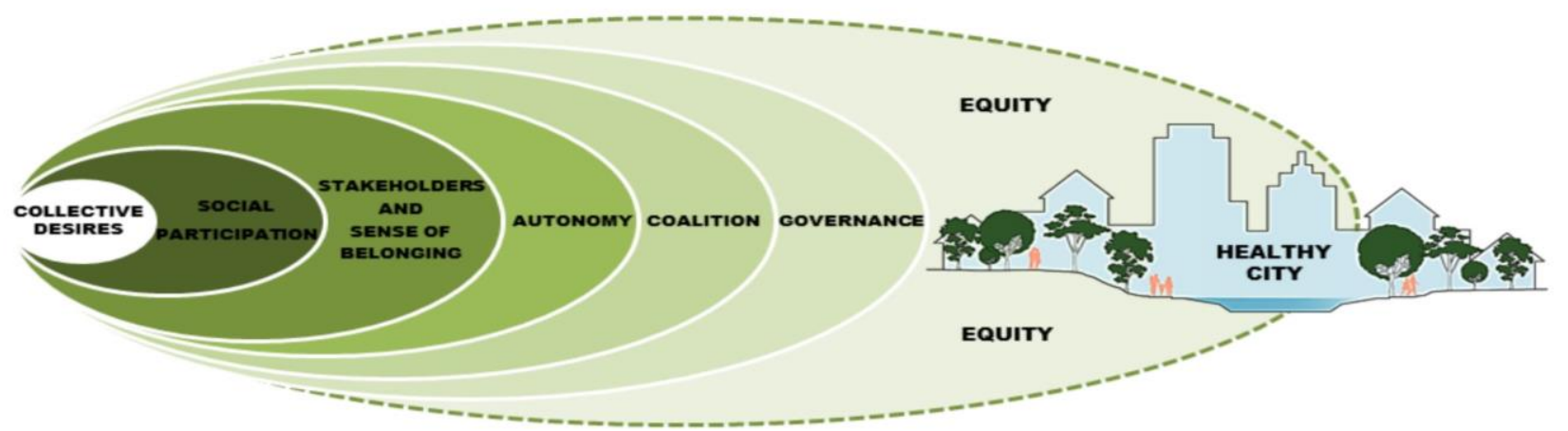

Source: Based on Sperandio et al. (2017).

The healthy cities development does not necessarily happen through all these steps. As, the steps can occur simultaneously: intersectoral coalitions may exist before there is a sense of belonging related to health promotion, for example. And the relations between the elements which are beneficial to healthy cities development are not linear, but there are feedback loops and conditional circumstances (DE LEEUW et al., 2014). So, this explanation does not intend to be a handbook of the unique form of developing a healthy city, but it can contribute to the theoretical importance of elements to a healthy city. Below, it is exposed the investigative procedure of the LWM.

\section{The process of identification of wishes through LWM}

The LWM is a tool created to enhance participative democracy, therefore enhance the healthy cities development. This tool is an investigative procedure which intends to seek different actors' wishes and find common values to improve the coalition formation.

In this article in shown some results of this investigative procedure conducted at Holambra City (located at Brazil). Holambra's city hall, in 2017, asked for collaboration 
to join the Potentially Healthy Cities Network (Rede de Municípios Potencialmente Saudáveis), which stimulates policies for healthy cities development in Brazil (RICE et al., 2017). So, the investigation procedure, which already was used at other cities that participate of this Network, was applied at Holambra in two places: the central area of the city and one rural region named Bairro do Fundão, because local stakeholders and managers indicated that this place has some constraints. But the results presented in this article were gathered in the central area (urban), because the number of participants of this area was greater.

\section{Procedures}

This investigative procedure is categorized as an Exploratory Research which aims to enable the development of methods to be used in more careful studies (BABBIE, 1986). The exploratory design was chosen, because the LWM is a simple procedure which can be applied even for municipalities at low resources condition at the beginning of the healthy city process.

The application of this tool has two phases, the first one is a conversation and the second one is the construction of the map where the sector's wishes are represented. At the first phase, there is a non-standardized conversation, because the public singularities must be understood. These singularities are related to some factors: socioeconomic condition, educational level, age, engagement about urban issues and the city's characteristics (or city's area). This conversation has a guide of questions, previously prepared, to promote the dialogue. The questions refer to understanding both healthy city and well-being; to understanding relations between urban planning and health promotion; to the dialogue forms between the sectors; and to the local specificities and their potential. The conversation can be done individually or in groups, and must be recorded transcribed.

The first phase is important to identify the conceptual and engagement level of individuals, as well as some of their needs and wishes. The relevance of question about what participants understand by "health" and "well-being" is due to the need of knowing if the population perceives that health promotion is not only related to healthcare, but also to the sectors of transportation, education, sanitation and others.

It is important that the first contact is friendly for the participants to feel comfortable to answer the questions. The conversation phase has a double function: data collection and enable the individual reflection about healthy city issues. The data collected in this phase can point to a conclusion when participants agree at some questions, but it can be seen only at data systematization.

At second phase, participants can talk and organize their wishes on the map, as is shown at Figure 2. The researcher who applies the LWM must conduct the group to make them identify wishes which are important to the collective interest, because the map intends to reveal the majority's wishes, not only from one individual. Pens and icons are available to the participants to use them to represent their wishes on the map. Each icon has a meaning, it can symbolize trees, parks, and others, as can be seen at Figure 3. The participants write and insert icons on the map, and then the result can be photographed.

There are variations in application of LWM. For example, instead of the participant group discuss and insert their wishes in the map simultaneously, the individuals can present their wishes sequentially. This flexibility is important to investigation be able to more situation. It can be used to study an area which passersby are asked if they want 
to participate of the research. So, there is a wishes overlap without contact between participants during the map construction.

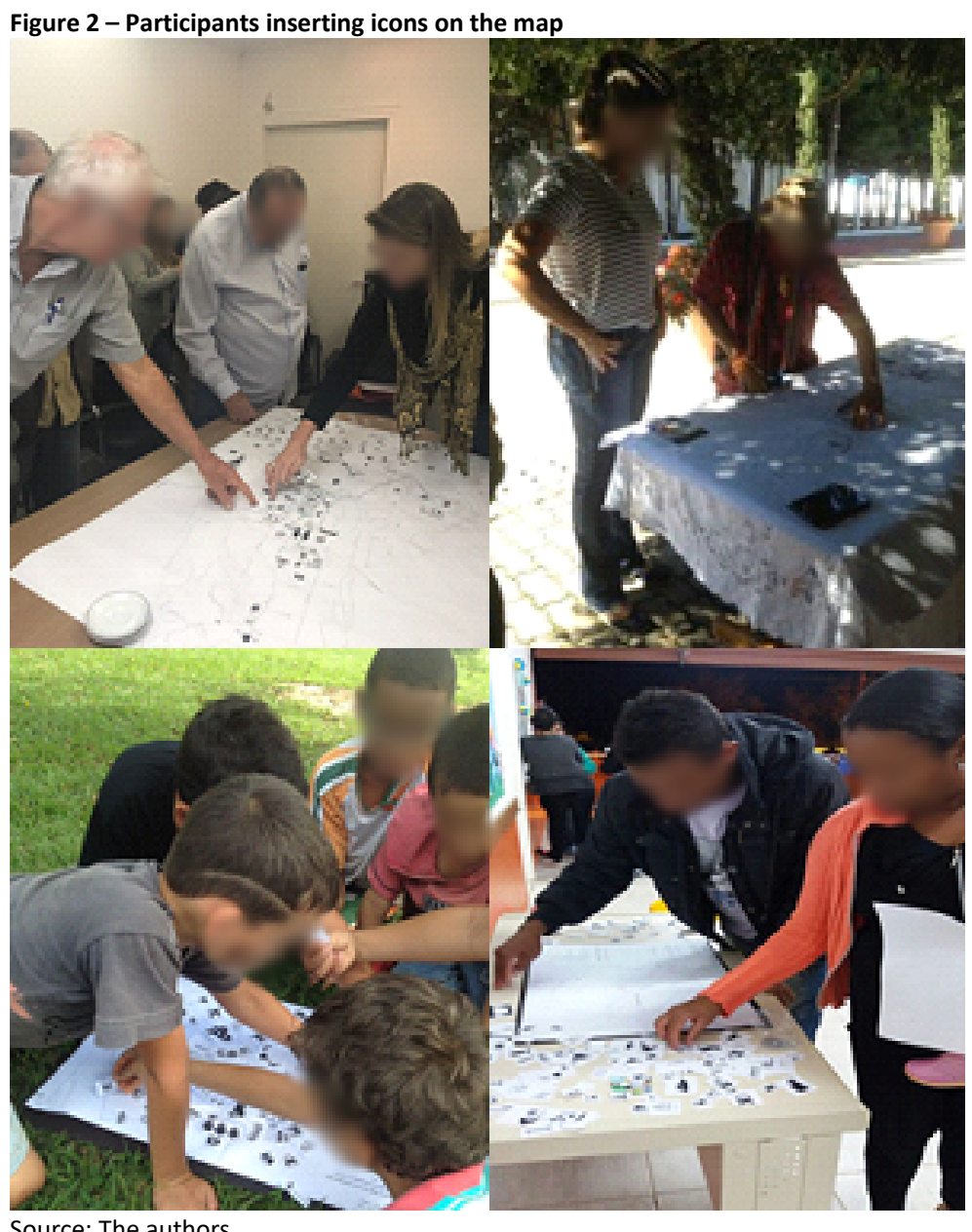

Source: The authors.

Figure 3 - Icons used by participants

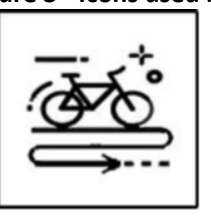

BIKE LANE

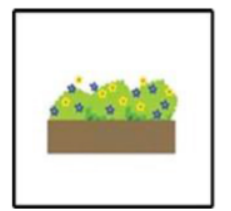

COMMUNITY GARDEN

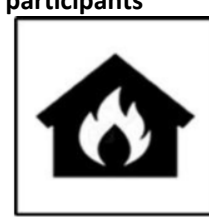

FIRE DEPARTMENT

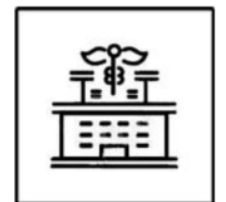

HOSPITAL

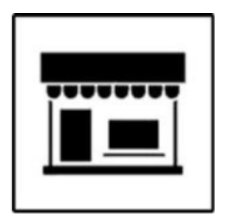

TRADE I SHOPS

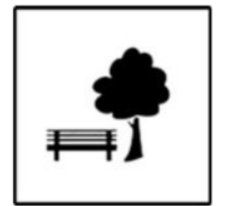

PARKS AND SQUARES

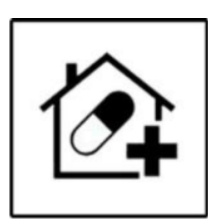

PHARMACY

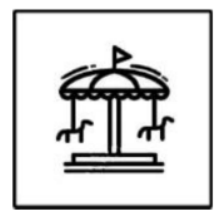

AMUSEMENT

PARK

Source: The authors.

\section{Design orientations}

Once the procedures were described, the orientations related to the LWM preparation will be presented. These orientations are related to three elements: initial questions, icons and maps. Then, the way the data systematized is done will be described. 
The questions are a support to conversation, it is expected that it does not be indiscriminately followed. The questions are related to four issues: (i) how individuals understand "healthy city"; (ii) how urban planning relates to health; (iii) intersectoral dialogue; and (iv) local particularities.

The first issue is investigated though asking questions as "You are a healthy person? Why?" or "Your city is a healthy city? Why?" This is important to investigate conceptualization level of participants.

The second issue covers the urban planning-health promotion relation. Therefore, questions as "Can urban planning promote health? How?" provide the data about this issue. This questioning makes the participant to think about the relation between urban planning and health promotion, which can be useful to generate ideas about the second phase of the investigation.

The third issue is concerned to how intersectoral dialogue is done, and how individuals wish that it was done. This data can be acquired through questions as "How government can create ways to listen to population?" This kind of questioning intends to gather information from a sector, about how the dialogue pathways can be. Discovering an effective dialogue form is useful to promote coalition formation between sectors.

The last issue of questions requires specific knowledge about the city or region. In these questions, it is beneficial that there is some local stakeholder to help with the questions' preparation (what happened in the Holambra's case). It can be useful for both participants and researchers, because local stakeholders have a priori information about local limitations and possibilities. So, this information can be integrated in questions. In the case of no possibility to access a stakeholder's assistance, generic question can be asked, "What is an issue that disturbs population?"

The selected icons must have a clear significance, because the participants have to be able to express themselves through these symbols without difficulty. The icons are essential when the participant does not know how to write, what unfortunately is not a rare event in some areas. Furthermore, it is beneficial that an excessive amount of icons cannot be used, because this can make the participant feel lost in an information pool. The restricted number of icons also must be avoided, so the participants are not be limited and would be able to express their wishes on the map.

The orientation of the map choice is related to the area in which participants have wishes and knowledge. The citizens from an urban neighborhood can have no knowledge and do not want any transformation at rural zones, but this situation can be different when the government is the investigated public. Thus, it is necessary to choose an adequate scale to the public, in order to allow the participant to have enough knowledge and familiarity with the area. So, they can be able to wish transformation in the investigated area.

\section{Identifying wishes}

Answers transcribed and maps with icons and annotation are the results of the LWM investigations. This study counted with the participation of 30 citizens from Holambra's central area ( $70 \%$ female, mean age $=41,17)$ and 07 municipal managers. The design of this method aimed the creation of a procedure able to be applied in different municipalities, especially those at low resource condition and at the beginning phase of policies creation for healthy city development. In order to a broader use of this 
exploratory investigation, there are no statistics restrictions for applying this method, except for a small number of participants.

The four issues listed above are investigated through answers transcribed. Two of these issues are related to a population diagnostics (conceptualization of healthy city, and relation between health promotion and urban planning), and the other two issues have a double function: to investigate how the participants understand the city and its power relations which change the local; and, to look into how they want that city to become, as well as its dialogue forms (how intersectoral dialogue can be done and city's specificities). The systematization of answers can be done with graphs and table, through grouping similar answers. For example, to the question "If you could change one thing in the city, what would you do?", the answers "I would like to take less time to arrive at my work" and "I would create more cycle tracks" can be both considered as "answers related to urban mobility".

Despite of the coalition formation can be one of indirect effects of the LWM, during conversation systematization, the differences must be shown, and therefore answers cannot be grouped in order to create an illusion of convergence. Thus, although it is possible to group answers to create a broad view, the unaligned ones must be looked at. Then, answers as "I would like safe places to walk" and "If there were more places to go with friends, I would be happier" can be grouped as "recreation wishes", each answer means different information. Through grouping answers, recreation can be understood as a demand, but the possible solutions have to be discriminated.

The maps systematization must focus at the most common wishes of a sector and at favors the majority. So, the map analyst creates a hierarchy to observe which wishes better suit to the collective interests. One map for each investigated sector can be created. In these maps, it must be clear what the common wishes of the sector are. Figure 4 shows an example.

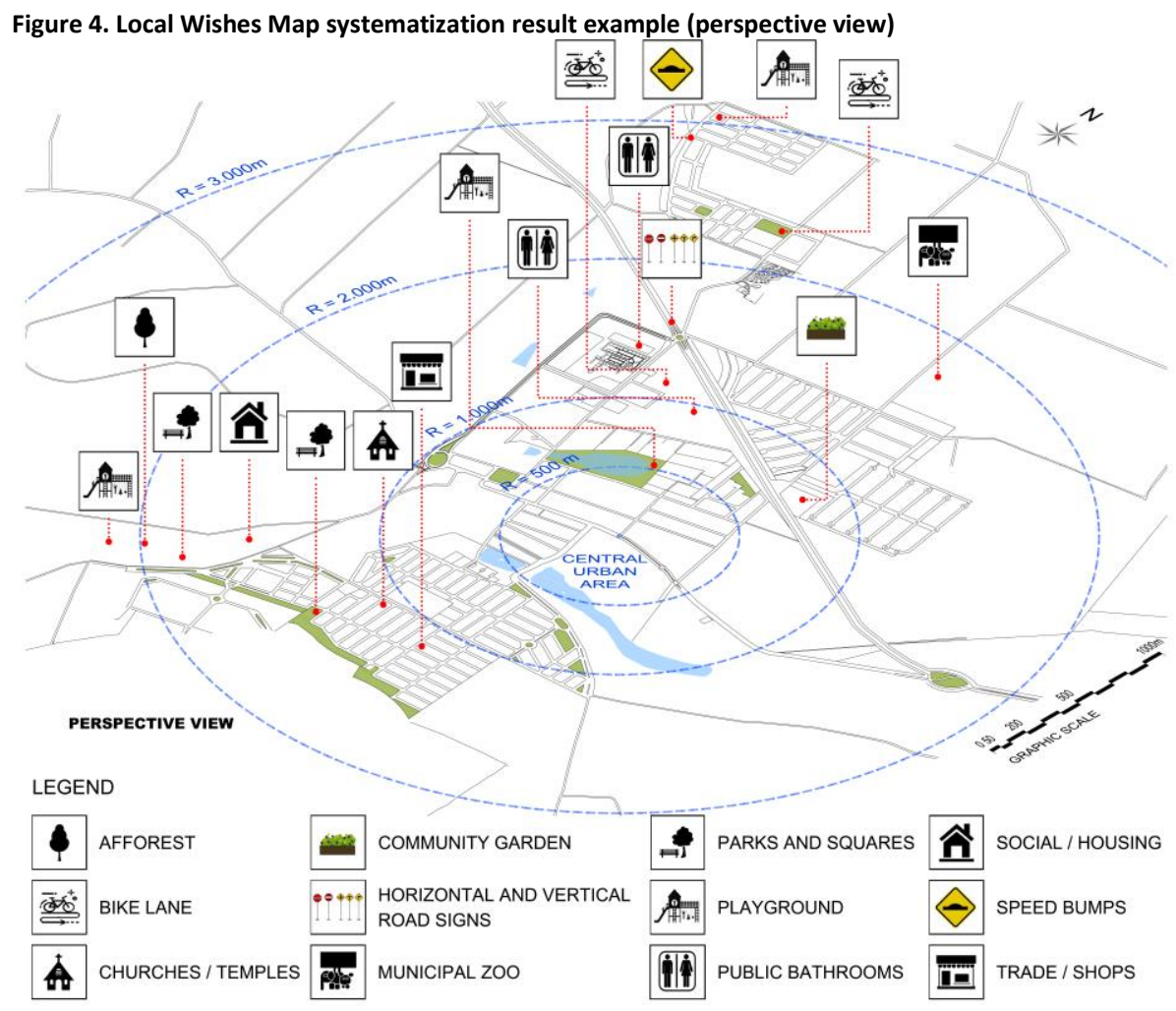

Source: The authors. 


\section{Conclusion}

The LWM has the necessary characteristics to be a tool for understanding demands between city's sectors, in order to enhance coalition formation. Thus, this instrument favors the potentization of creative forces, because the coalitions have the nature of generating forces through sectoral collaboration. Also, these procedures are able to shed light on an apparently chaotic situation, which are the different demands related to public space and to health promotion policies. For instance, in the study case, population tended to wish specific issues as trees and speed bumps while managers had the propensity for structural issues as industries, even with common wishes (Figure 4).

The activity that is taken by population which helps the conduction of the LWM already is a participative act. Thus, this tool can favor the citizen's sense of belonging, when the population perceives that their demands were formally expressed and it can be embodied in the proposal project of the healthy city. Therefore, the LWM provides a tool for the population to became a public (a group of individuals who participate of public sphere through dialogue in order to find the common good).

The LWM becomes a tool of participative and democratic governance that can be applied at cities which do not have financial resources enough to use expensive methods. Also, this procedure can be applied at the first moment of the healthy city development, as happened with Holambra, then, be used to monitor the city's progress. Thus, LWM can favor the achievement of 2030 Agenda for Sustainable Development goals (UNITED NATIONS GENERAL ASSEMBLY, 2015).

Therefore, this investigative procedure, through democratic values, can be an important tool for the healthy cities' development, even at low resources condition. Because it can encourage and systematize the collective wishes, in order to find consensus about the urban planning of a healthy city. This tool can be applied in other cities and the systematization must to be attended for improving the LWM.

\section{Acknowledgment}

Thanks to the City Hall of Holambra, São Paulo - Brazil, for supporting this study.

\section{References}

ARONSON, R. E.; NORTON, B. L.; KEGLER, M. C. Achieving a “Broad View of Health". Health Education \& Behavior, v. 34, n. 3, p. 441-452, 26 jun. 2007. DOI: https://doi.org/10.1177/1090198106289000

BABBIE, E. The practice of social research. 4th. ed. Belmont, Ca: Wadsworth publishing, 1986.

BRANDÃO, I. Aspectos Importantes Para Um Município Que Quer Ser Saudável. In: SPERANDIO, A. M. G.; MACHÍN, D. G.; FORTUNATO, M. A. B. (Eds.). . Políticas Integradas em Rede e a Construção de Espaços Saudáveis: boas práticas para a Iniciativa do Rostos, Vozes e Lugares. 1. ed. Brasília, Brazil: Organização Pan-Americana da Saúde, 2010. p. 31-60.

BRASIL. Ministério da Saúde. Secretaria de Vigilância à Saúde. Secretaria de Atenção à Saúde. Política Nacional de Promoção da Saúde (PNaPS) revisão da Portaria MS/GM n 687, de 30 de março de 2006 / Ministério da Saúde, Secretaria de Vigilância à Saúde, Secretaria de Atenção à Saúde. - Brasília: Ministério da Saúde, 2014.

BURRIS, S. et al. Emerging Strategies for Healthy Urban Governance. Journal of Urban Health, v. 84, n. S1, p. 154163, 27 maio 2007. DOI: https://doi.org/10.1007/s11524-007-9174-6 
CLAVIER, C.; O'NEILL, M. The Role of Policy Coalitions in Understanding Community Participation in Healthy Cities Projects. In: Healthy Cities. New York, NY: Springer New York, 2017. p. 359-373. DOI: https://doi.org/10.1007/978-14939-6694-3_14

DE ANDRADE, L. O. M. et al. Social determinants of health, universal health coverage, and sustainable development: Case studies from Latin American countries. The Lancet, v. 385, n. 9975, p. 1343-1351, 4 abr. 2015. DOI: https://doi.org/10.1016/S0140-6736(14)61494-X

DE LEEUW, E. et al. Healthy Cities, Promoting health and equity - evidence for local policy and practice. Cambridge: WHO Regional Office for Europe, 2014.

DE LEEUW, E. From Urban Projects to Healthy City Policies. In: Healthy Cities. New York, NY: Springer New York, 2017. p. 407-437. DOI: https://doi.org/10.1007/978-1-4939-6694-3_17

DINERSTEIN, A. C. The Politics of Autonomy in Latin America. London: Palgrave Macmillan UK, 2015. DOI: https://doi.org/10.1057/9781137316011

DOORIS, M.; HERITAGE, Z. Healthy Cities: Facilitating the Active Participation and Empowerment of Local People. Journal of Urban Health, v. 90, n. S1, p. 74-91, 29 out. 2013. DOI: https://doi.org/10.1007/s11524-011-9623-0

HABERMAS, J. The structural transformation of the public sphere : an inquiry into a category of bourgeois society. Cambridge: Massachusetts Institute of Technology Press (Original work published 1962), 1989.

KICKBUSCH, I.; GLEICHER, D. Governance for health in the 21st century. Copenhagen, Denmark: WHO Regional Office for Europe, 2012.

LAMBERT, N. M. et al. To Belong Is to Matter. Personality and Social Psychology Bulletin, v. 39, n. 11, p. 1418-1427, 15 nov. 2013. DOI: https://doi.org/10.1177/0146167213499186

MILES, S. Stakeholder Theory Classification: A Theoretical and Empirical Evaluation of Definitions. Journal of Business Ethics, v. 142, n. 3, p. 437-459, 8 maio 2017. DOI: https://doi.org/10.1007/s10551-015-2741-y

PEDERSON, A.; ROOTMAN, I. From Health Care to the Promotion of Health: Establishing the Conditions for Healthy Communities in Canada. In: Healthy Cities. New York, NY: Springer New York, 2017. p. 43-61. DOI:

https://doi.org/10.1007/978-1-4939-6694-3_3

RICE, M. et al. Healthy Municipalities, Cities and Communities in Latin America: Strong Histories, Committed Futures. In: Healthy Cities. New York, NY: Springer New York, 2017. p. 151-213. DOI: https://doi.org/10.1007/978-14939-6694-3_8

SIMOS, J.; DE LEEUW, E. Wrap-Up: Values and Governance for Urban Health. In: Healthy Cities. New York, NY: Springer New York, 2017. p. 341-357. DOI: https://doi.org/10.1007/978-1-4939-6694-3_13

SORENSEN, G. Our Global Neighbourhood. Bulletin of the Atomic Scientists, v. 51, n. 4, p. 69-73, 1 jul. 1995.

SPERANDIO, A. M. G. et al. Reverberação Política e Educativa para Cidade Saudável. Cadernos de Pós-Graduação em Arquitetura e Urbanismo, v. 17, n. 2, p. 26-51, 11 dez. 2017. DOI:

https://doi.org/10.5935/cadernosarquitetura.v17n2p26-51

SPERANDIO, A. M. G.; FRANCISCO FILHO, L. L.; MATTOS, T. P. Health promotion policy and urban planning: joint efforts for the development of healthy cities. Ciência \& Saúde Coletiva, v. 21, n. 6, p. 1931-1938, jun. 2016. DOI: http://dx.doi.org/10.1590/1413-81232015216.10812016

TSOUROS, A. D. Healthy Cities: A Political Project Designed to Change How Cities Understand and Deal with Health. In: Healthy Cities. New York, NY: Springer New York, 2017. p. 489-504. DOI: https://doi.org/10.1007/978-1-49396694-3_21 
SPERANDIO, Ana Maria Girotti et al.

Local wishes map as a tool for promoting dialogue and developing healthy cities

UN HABITAT. The Global Campaign on Urban Governance: Concept Paper. 2002.

UNITED NATIONS GENERAL ASSEMBLY. Transforming our world: The 2030 agenda for sustainable development. $\mathrm{A} / \mathrm{RES} / 70 / 1,2015$.

WERNA, E. et al. Healthy City Projects in Developing Countries : an International Approach to Local Problems. [s.I.] Taylor and Francis, 2014.

WORLD HEALTH ORGANIZATION. Global Report on Urban Health. WHO, 2016.

YUVAL-DAVIS, N. Belonging and the politics of belonging. Patterns of Prejudice, v. 40, n. 3, p. 197-214, jul. 2006. DOI: https://doi.org/10.1080/00313220600769331

\footnotetext{
${ }^{1}$ Ana Maria Girotti Sperandio

Orthopedist specialist in public health. $\mathrm{PhD}$ in public health, post-doctor in collective health and postdoctoral in urban planning and health cities. Postal address : Av. Saturnino de Brito, 224 - Cidade Universitária, Campinas - SP, Brazil, CEP 13083-889

\section{${ }_{2}$ Murilo Urssi Malek-Zadeh}

Civil Engineer. Master of Science, Graduate student at the Graduate Program in Civil Engineering of FEC-UNICAMP. Postal address: R. Saturnino de Brito, 224 - Cidade Universitária, Campinas - SP, Brazil, CEP 13083-889

\section{João Luiz de Souza Arêas}

Architect and Urbanist. Postal address: Av. Eng. Carlos Reinaldo Mendes, 3041 - Alto da Boa Vista, Sorocaba - SP, Brazil, CEP 18013-280

\section{Lauro Luiz Francisco Filho}

Architect and Urbanist. Assistant Professor in urban planning da FEC-UNICAMP. Postal address: R. Saturnino de Brito, 224 - Cidade Universitária, Campinas - SP, Brazil, CEP 13083-889
} 